\title{
Smith Antibody Measurement
}

National Cancer Institute

\section{Source}

National Cancer Institute. Smith Antibody Measurement. NCI Thesaurus. Code C92281.

The determination of the amount of Smith antibody present in a sample. 